Article

\title{
Norovirus Detection in Ready-To-Eat Salads by Propidium Monoazide Real Time RT-PCR Assay
}

\author{
Valentina Terio ${ }^{1, *(\mathbb{D}}$, Patrizio Lorusso ${ }^{1}$, Anna Mottola ${ }^{1}{ }^{\mathbb{D}}$, Canio Buonavoglia ${ }^{1}$, \\ Giuseppina Tantillo $^{2}$, Elisabetta Bonerba ${ }^{1}$ (D) and Angela Di Pinto ${ }^{1}$ \\ 1 Department of Veterinary Medicine (DIMEV), University of Bari, 70010 Valenzano, Italy; \\ lorusso.patrizio@libero.it (P.L.); anna.mottola@uniba.it (A.M.); canio.buonavoglia@uniba.it (C.B.); \\ elisabetta.bonerba@uniba.it (E.B.); angela.dipinto@uniba.it (A.D.P.) \\ 2 Department of Interdisciplinary Medicine, University of Bari, 70124 Bari, Italy; giuseppina.tantillo@uniba.it \\ * Correspondence: valentina.terio@uniba.it
}

Received: 24 June 2020; Accepted: 24 July 2020; Published: 28 July 2020

\begin{abstract}
Ready-to-eat (RTE) salads have recently been associated with food-borne norovirus outbreaks, although these infections are mainly related to shellfish and berry consumption in the EU. A total of 135 bagged RTE vegetables were analyzed in order to investigate the occurrence of norovirus (NoV) genotype I (GI) and II (GII) RNA and to differentiate between infectious and non-infectious viruses by using propidium monoazide (PMAxx) coupled with the real time Reverse Transcription (RT) PCR method. Initially, the PMAxx real time RT-PCR assay was optimized on NoV GI and GII suspensions, and proved capable of detecting significant $(p<0.05)$ differences between infectious and inactivated viruses. Our analysis conducted on RTE salads samples showed the presence of norovirus GII in $74.8 \%$ of samples, of which $37.6 \%$ were infectious. The samples tested for viral contamination came from only two RTE vegetable-processing plants. The findings in this study could also be due to virally-contaminated water used in food production, processing, or preparation. This study stresses the need for effective real-time RT-PCR tools capable of qualitative and quantitative detection of NoV RNA, as well as being able to measure virus infectivity, for risk assessment, which is crucial in several public health measures and food regulations.
\end{abstract}

Keywords: NoV GI and GII; RTE salads; molecular assay; food safety; PMAxx Real Time RT-PCR; foodborne viruses; public health

\section{Introduction}

Food and water-borne outbreaks reported in Europe in 2018 were related to bacterial agents $(57.0 \%$ of all outbreaks), bacterial toxins (24.2\%), and viruses (13.5\% of all outbreaks). Among the causative agents, viruses are recognized as important emerging pathogens of food-borne disease [1]. The main food sources of enteric viruses were crustaceans, shellfish, mollusks, mixed food, buffet meals, water, fish and fishery products, and food of non-animal origin [2].

During the last two decades, enteric viruses have frequently been detected in vegetables $[3,4]$. In particular, leafy green vegetables and ready-to-eat (RTE) salads, consumed raw and typically with no further washing/decontamination procedures, are considered an important route of transmission of human enteric viruses $[3,5,6]$. Vegetables may become contaminated by enteric viruses during pre-harvest cultivation through the improper use of organic waste in agricultural land in the form of fertilizer, fecal pollution in irrigation waters, or through direct contamination by livestock, wild animals, and birds. In addition, improper food handling practices should be taken into consideration [4,6-8].

The current European legislation on microbiological criteria for foodstuffs, Commission Regulation (EC) No 2073/2005 [9], lays down food-safety criteria for relevant foodborne bacteria in pre-cut 
(ready-to-eat) fruit and vegetables, such as Salmonella spp. and Listeria monocytogenes, and the process hygiene criteria, e.g., addressing Escherichia coli, applicable, respectively, to products placed on the market or to production processes $[6,8,10]$. Given the lack of any sufficiently-developed analytical methods and prevalence studies and quantitative data on viral occurrence in leafy green vegetables consumed raw, the legislation does not currently take into consideration the role of viruses as foodborne pathogens in this matrix [10].

The current gold standard for detecting enteric viruses is reverse transcription real time PCR (real time RT-PCR) [11,12]. Indeed, the horizontal method for determining the hepatitis A virus and norovirus in food uses real time RT-PCR for detection and quantification [13].

Despite being a very sensitive technique, PCR has some limitations for food viral analysis in that it has trouble differentiating between infectious and inactivated viruses [14], consequently preventing an efficient risk assessment [15]. Viral infectivity is necessary to assess the cytopathic effects (CPE) in susceptible cell lines [16]. However, not all viruses, such as noroviruses, are able to grow in a cell line in vitro. Therefore, the use of nucleic acid intercalating dyes such as propidium monoazide (PMAxx), is a powerful problem-solving tool [14,17]. Viability dyes are able to enter into damaged or destroyed capsids. Once it has penetrated, the dye intercalates covalently into RNA after exposure to strong visible light, thus interfering with DNA amplification. The rest of the genome, including that found in undamaged capsids, is unaffected by PMAxx and can be amplified with PCR [18-20].

Given the considerable public health implications and very low infectious dose of human noroviruses (10-100 viral particles) [21], the aim of this work is to investigate the occurrence of genogroups GI and GII of norovirus (NoV) RNA in RTE salads following ISO 15216-2 (2017) and to provide an assessment of PMAxx real time RT-PCR assay feasibility in order to discriminate between native and inactivated noroviruses.

\section{Materials and Methods}

\subsection{Virus Strains}

Norovirus genogroup I, genotype 2 (GI.2) and genogroup II, genotype 4 (GII.4 variant Sidney 2012) suspensions (kindly provided by Prof. Martella, Department of Veterinary Medicine, University of Bari, Valenzano, Italy) diluted by $1 / 10 w / v$ of positive stool samples in DMEM (SIGMA) were used as positive controls. Then, aliquots of the viruses were stored at $-80^{\circ} \mathrm{C}$ until use.

\subsection{PMAxx Real Time RT-PCR Validation}

\subsubsection{PMAxx Pretreatment on Virus Suspensions}

The validation of PMA real time RT-PCR was performed using differently-treated positive controls. GI and GII viral positive control suspensions were subdivided as follows: (i) $250 \mu \mathrm{L}$ untreated viral suspensions; (ii) $250 \mu \mathrm{L}$ viral suspensions treated with $50 \mu \mathrm{M}$ PMAxx (Biotium) and 0.5\% Triton 100-X (Thermo Fisher Scientific, Roma, Italy) in DNA LoBind $1.5 \mathrm{~mL}$ tubes (Eppendorf) at room temperature (RT) for $10 \mathrm{~min}$ in a shaker at $150 \mathrm{rpm}$; (iii) $250 \mu \mathrm{L}$ viral suspensions thermally inactivated at $95^{\circ} \mathrm{C}$ for $5 \mathrm{~min}$; (iv) $250 \mu \mathrm{L}$ viral suspensions thermally inactivated at $95^{\circ} \mathrm{C}$ for five minutes and treated with $50 \mu \mathrm{M}$ PMAxx (Biotium) and 0.5\% Triton 100-X (Thermo Fisher Scientific) in DNA LoBind $1.5 \mathrm{~mL}$ tubes (Eppendorf) at room temperature (RT) for $10 \mathrm{~min}$ at $150 \mathrm{rpm}$. In order to obtain a covalent bond with PMA and RNA, the viral suspensions were immediately exposed to fifteen minutes photoactivation using a photoactivation system (Led-ActiveBlue, GenIUL) [22]. Then RNA was extracted using the NucliSens ${ }^{\circledR}$ miniMAG magnetic kit (BioMérieux), in compliance with ISO/TS 15216-2 (2017).

\subsubsection{Real Time RT-PCR}

The real time RT-PCR was conducted following ISO/TS 15216-2 (2017) in terms of primers used and experimental conditions with the inclusion of an internal amplification control (IAC). The reaction 
was performed using the RNA UltraSense ${ }^{\mathrm{TM}}$ One-Step Quantitative RT-PCR System (Thermo Fisher Scientific), a $250 \mathrm{nM}$ probe (labelled with FAM), $500 \mathrm{nM}$ forward primer, $900 \mathrm{nM}$ reverse primer, $50 \mathrm{nM}$ IAC probe (labelled with VIC), and 300 copies of IAC [23]. The ORF 2 region was the target of the utilized primers. For NoV GI, forward primer QNIF4, reverse primer NV1 LCR, and probe NV1LCpr were employed; for NoV GII, forward primer QNIF2d, reverse primer COG2R, and probe QNIFS were used [24]. Then, to reach a final reaction volume of $50 \mu \mathrm{L}$, we added $20 \mu \mathrm{L}$ of RNA. The real time RT-PCR conditions were $5 \mathrm{~min}$ at $95^{\circ} \mathrm{C}$, followed by 45 cycles of $15 \mathrm{~s}$ at $95^{\circ} \mathrm{C}$ and $1 \mathrm{~min}$ at $60^{\circ} \mathrm{C}$ and $1 \mathrm{~min}$ at $65^{\circ} \mathrm{C}$. Each experiment was carried out in duplicate and repeated twice. All amplification plots were checked to determine false-positive results due to any high or unbalanced background signals. In addition, true positive fluorescent plots were checked to ensure that the $\mathrm{Ct}$ value generated by the analysis software corresponded to the exponential phase of amplification for the reaction, as indicated by ISO 15216 (2017).

The photoactivable dye used cannot penetrate intact capsids but is capable of entering destroyed or damaged capsids. Once inside, the photoactivable dye intercalates covalently into RNA after exposure to strong visible light, impeding real time RT-PCR amplification. Viral inactivation was evaluated by the $\mathrm{Ct}$ values of different kinds of positive controls, as described above (Section 2.2.1).

\subsection{Detection of NoV GI and GII with PMAxx Real Time RT-PCR}

\subsubsection{Sampling}

A total of 135 bagged ready-to-eat vegetables from two different Italian leafy green vegetable enterprises were collected from October 2017 to March 2018. They included 21 mixed salads, 9 carrot (Daucus carota subsp. sativus), 33 valerian (Valeriana officinalis), 9 rocket (Eruca vesicaria), 15 spinach (Spinacia oleracea), 21 iceberg (Lactuca sativa), 6 romaine lettuce (Lactuca sativa L var. longifolia), 9 chicory (Cichorium intybus var. foliosum), 9 curly leaf endive (Cichorium endivia var. crispum), and 3 trevisano chicory (Cichorium intybus L. subsp. intybus). All samples were analyzed before the expiration date labelling (up to 8 days). Samples were transported to the laboratory at temperatures $<8{ }^{\circ} \mathrm{C}$ and immediately analyzed.

\subsubsection{Virus Concentration and Nucleic Acid Extraction}

Viruses concentration and viral RNA extraction were performed following the method specified by ISO/TS 15216-2 (2017) for the qualitative detection of NoV genogroups I (GI) and II (GII) from RTE salad samples. Briefly, $25 \mathrm{~g}$ of each sample were cut into little pieces and homogenized with TGBE buffer $\mathrm{pH} 9.5$ (100 mM Tris- $\mathrm{HCl}, 50 \mathrm{mM}$ glycine, $1 \%$ beef extract) and $10 \mu \mathrm{L}$ of process control virus material (Mengo virus, kindly provided by IZS Foggia, Italy). The eluate was concentrated with 5X PEG/NaCl solution ( $50 \%(w / v)$ PEG $8000,1.5 \mathrm{M} \mathrm{NaCl})$. The pellet obtained was resuspended in $500 \mu \mathrm{L}$ of PBS buffer $\mathrm{pH} 9.5$ ( $0.15 \mathrm{M}$ sodium phosphate) and divided into two aliquots $(250 \mu \mathrm{L})$. With the aim of discriminating between native and inactivated viruses, one aliquot $(250 \mu \mathrm{L})$ was treated with PMAxx-Triton $x-100$ as previously described $[14,17,19,22]$. In brief, $250 \mu \mathrm{L}$ of each aliquot obtained as described above were incubated with $50 \mu \mathrm{M}$ PMAxx (Biotinum) and 5\% Triton X-100 in the dark at RT for $10 \mathrm{~min}$ [17]. Samples were then exposed to light for $15 \mathrm{~min}$ using a photoactivation system (Led-ActiveBlue, GenIUL). Then, the viral nucleic acids were extracted and purified using a commercial kit (NucliSENS miniMAG kit, bioMérieux, Firenze, Italy) following the manufacturer's standard protocols. All RNA obtained was subjected to real time RT-PCR in compliance with ISO/TS 15216-2 (2017), and each experiment was carried out in duplicate and repeated twice.

\subsubsection{Mengovirus Real Time RT-PCR}

In accordance with ISO/TS 15216-2 (2017), Mengo virus real time RT-PCR was conducted in order to assess extraction efficiency. Briefly, the assay was performed using an RNA UltraSense ${ }^{\mathrm{TM}}$ One-Step Quantitative RT-PCR System (Thermo Fisher Scientific), $250 \mathrm{nM}$ probe (labeled with 
FAM), $500 \mathrm{nM}$ forward primer, and $900 \mathrm{nM}$ reverse primer. The used primers amplify a region between 110 and 209 nucleotides corresponding to the deletant mengo virus strain $\mathrm{MC}_{0}$, giving a product of $100 \mathrm{bp}$; forward primer Mengo110 (5'-GCGGGTCCTGCCGAAAGT-3'), reverse primer Mengo209 (5'-GAAGTAACATATAGACAGACGCACAC-3'), and probe Mengo147 (5'FAM-ATCACATTACTGGCCGAACG-BNFQ3') were employed. Mengo virus RNA was extracted by heating the virus at $95^{\circ} \mathrm{C}$ for $5 \pm 0.5 \mathrm{~min}$, chilling, and centrifuging at $\geq 3.000 \mathrm{~g}$ for $1 \mathrm{~min}$. Then, the supernatant containing virus RNA was used as a template. The standard curve was performed by adding $5 \mu \mathrm{L}$ of undiluted, $10^{-1}, 10^{-2}$, and $10^{-3}$ mengo virus RNA to $20 \mu \mathrm{L}$ of RNA UltraSense ${ }^{\mathrm{TM}}$ One-Step Quantitative RT-PCR System (Thermo Fisher Scientific). The thermocycling conditions included an RT step at $55^{\circ} \mathrm{C}$ for $1 \mathrm{~h}$, followed by $5 \mathrm{~min}$ at $95^{\circ} \mathrm{C}$ and 45 cycles of $15 \mathrm{~s}$ at $95^{\circ} \mathrm{C}, 1 \mathrm{~min}$ at $60^{\circ} \mathrm{C}$, and $1 \mathrm{~min}$ at $65^{\circ} \mathrm{C}$. Curves with at least three points close to the line of the best fit and Pearson's coefficients of determination (R2) values $>0.98$ were used for calculations. The percentage extraction efficiency for each sample was determined by comparing the Ct values for the sample RNA extract with those for the mengo virus dilution series. Any sample with an extraction efficiency of $<1 \%$ was re-analyzed, first by re-extracting the viral RNA from the stored homogenate, then by testing the stored RTE salads. Results for any sample giving three extraction efficiency results of $<1 \%$ were considered invalid.

\subsection{Statistical Analysis}

Total validation tests were performed in duplicate and repeated twice. Comparisons between means were carried out using student t-test (unpaired) in Microsoft Excel 2016.

\section{Results}

\subsection{PMA Real Time RT-PCR Assay Validation}

The optimization of PMAxx real time RT-PCR assay shows that NoV GI and GII suspensions were inactivated by incubation at $95{ }^{\circ} \mathrm{C}$ for 5 min followed by incubation with $50 \mu \mathrm{M}$ PMAxx and $0.5 \%$ Triton 100-X (Thermo Fisher Scientific) and irradiation using continuous light. Results, shown in Table 1, indicate that the use of PMAxx-Triton highlighted significant $(p<0.05)$ differences between native viral particles and inactivated viruses, indicating a reduction rate of -7.69 and -8.06 for NoV GI and NoV GII, respectively (Table 1). The reduction rate was computed as the differences between the Ct values obtained.

\subsection{Detection of NoV GI and GII by Real Time RT-PCR}

The results obtained from virological analysis of 135 RTE vegetable samples are summarized in Table 2.

The presence of NoV GII was detected in 101/135 (74.8\%) of the analyzed samples, and 38/101 samples with NoV GII (37.6\%) were infectious. NoV GI was not detected in the samples analyzed. The detailed results were as follows: 17 mixed salad samples were NoV GII RNA-positive (80.9\%), of which 6 were infectious (28.6\%); 8 carrot samples $(88.8 \%)$, of which 2 were infectious $(22.2 \%)$; 27 valerian samples $(81.8 \%)$, of which 9 were infectious $(27.3 \%)$; 5 rocket samples $(55.6 \%)$, of which no sample contained infectious viral particles; 15 spinach samples $(100 \%)$, of which 6 were infectious $(40 \%)$; 15 iceberg lettuce samples (71.4\%), of which 9 were infectious (42.9\%); 8 curly leaf endive samples $(88.9 \%)$, of which 3 were infectious (33.3\%); and 6 chicory samples $(66.7 \%)$, of which 3 were infectious $(33.3 \%)$ (Table 2). The mean viral extraction efficiency of the process was $>1 \%$ for each sample. 
Table 1. Results of real time RT-PCR for norovirus (NoV) genotypes I and II (GI and GII) detection after different treatment. Table explanation: The significant values for method validation are as follows: The first value of reduction rate (-5.12) refers to the NoV GI treated only with PMAxx compared with the non-treated NoV GI; the third value of reduction rate (-7.69) refers to the NoV GI treated with PMAxx and high temperature compared with the non-treated NoV GI. In the same way, it is possible observe a reduction rate of -4.10 between NoV GII treated with only PMAxx and the non-treated NoV GII and a reduction rate of -8.06 between NoV GII treated with PMAxx and high temperature and the non-treated NoV GII.

\begin{tabular}{|c|c|c|c|}
\hline Viruses & Treatment & Ct Value & Reduction \\
\hline \multirow{4}{*}{ NoV GI } & NT & $28.66 \pm 0.23$ & - \\
\hline & PMAxx $[50 \mu \mathrm{M}]$ & $33.79 \pm 0.19$ & $-5.12 \pm 0.37 *$ \\
\hline & $95^{\circ} \mathrm{C}$ & $32.79 \pm 0.19$ & $-3.92 \pm 0.18$ \\
\hline & $95^{\circ} \mathrm{C}+\operatorname{PMAxx}[50 \mu \mathrm{M}]$ & $36.35 \pm 0.78$ & $-7.69 \pm 0.96$ * \\
\hline \multirow{4}{*}{ NoV GII } & NT & $28.59 \pm 0.31$ & - \\
\hline & PMAxx $[50 \mu \mathrm{M}]$ & $32.70 \pm 0.18$ & $-4.10 \pm 0.27$ * \\
\hline & $95^{\circ} \mathrm{C}$ & $33.41 \pm 0.32$ & $-4.82 \pm 0.52$ \\
\hline & $95^{\circ} \mathrm{C}+\operatorname{PMAxx}[50 \mu \mathrm{M}]$ & $36.70 \pm 0.25$ & $-8.06 \pm 0.27$ * \\
\hline
\end{tabular}

Legend: $\mathrm{NT}=$ not treated; PMAxx $=$ propidium monoazide. ${ }^{*} p$ value $<0.05$.

Table 2. Results of NoVs GII RNA detection in ready-to-eat (RTE) salad pre- and post-treatment with PMAxx $[50 \mu \mathrm{M}]$.

\begin{tabular}{ccc}
\hline \multirow{2}{*}{ Samples } & \multicolumn{2}{c}{ NoV GII Positive } \\
\cline { 2 - 3 } & Pre-Treatment & Post-Treatment \\
\hline Mixed salad & $17 / 21(80.9 \%)$ & $6 / 21(28.6 \%)$ \\
Carrot & $8 / 9(88.8 \%)$ & $2 / 9(22.2 \%)$ \\
Valerian & $27 / 33(81.8 \%)$ & $9 / 33(27.3 \%)$ \\
Rocket & $5 / 9(55.6 \%)$ & $0 / 9$ \\
Spinach & $15 / 15(100 \%)$ & $6 / 15(40 \%)$ \\
Iceberg Lettuce & $15 / 21(71.4 \%)$ & $9 / 21(42.9 \%)$ \\
Romaine Lettuce & $0 / 6$ & $0 / 6$ \\
Curly Leaf Endive & $8 / 9(88.9 \%)$ & $3 / 9(33.3 \%)$ \\
Chicory & $6 / 9(66.7 \%)$ & $3 / 9(33.3 \%)$ \\
Trevisano Chicory & $0 / 3$ & $0 / 3$ \\
Total Samples & $101 / 135(74.8 \%)$ & $38 / 135(28.1 \%)$ \\
\hline
\end{tabular}

\section{Discussion}

Noroviruses are frequently being identified as common causes of acute gastroenteritis (AGE), and their true burden is largely underestimated [25].

Noroviruses may contaminate food at any stage in the food supply chain, and transmission to humans can take place by ingestion of food contaminated either during the production process (during either primary production or further processing), or else by infected food handlers. Food can act as a vehicle for transmitting viruses to people. Enteric viruses will not propagate outside a host nor in foods, but may remain for a long time as infectious particles in food, and can live on in an infectious state until the foods are consumed [26].

Although food-borne NoV outbreaks have largely been linked to shellfish consumption in Europe $[27,28]$, other matrices such as frozen red fruits have recently been associated with such infections $[29,30]$.

Moreover, viruses have been implicated in cases of food-borne illness linked with contaminated leafy green vegetables and related ready-to-eat products [6,31,32]. 
In this study, the high prevalence of NoV in RTE salads, observed using the standard method for NoV in foodstuffs developed by the European Committee of Standardization (ISO/TS 15216-2:2017), may explain the data from the European Food Safety Authority reporting a rise in the number of NoV outbreaks due to consumption of vegetables in Europe [2]. However, the data on the occurrence of NoV in the present study are higher than those reported by other authors. Specifically, Serracca et al. (2012) [33] found all ready-to-eat vegetable (100\%) samples to be negative for Hepatitis A virus (HAV) while observing percentages of between $11.9 \%$ and $15.5 \%$ in RTE vegetables and red soft fruit, respectively, for NoV. In addition, Loutreul et al. (2014) detected NoV in $13.6 \%$ of vegetable samples, lower than the results from our study. Therefore, the high occurrence of $\mathrm{NoV}$ observed in this study may have been biased by the limited sampling plan. Indeed, the samples tested for viral contamination came from only two RTE vegetable-processing plants. Therefore, the high presence of NoV makes it appropriate to investigate the water used on the two farms that supplied the samples of RTE salad subjected to analysis. Indeed, the high prevalence of viruses detected could potentially be an indicator of ineffective washing during the production process [34,35]. Furthermore, it should be noted that these two vegetable-processing plants were chosen because they are the best-known brands on the Italian market and in order to sample different types of ready-to-eat salads.

The findings in this study could also be due to virally-contaminated water, e.g., from an adjacent wastewater outflow, that was used in food production, processing, or preparation. Virus-contaminated water used for irrigation can be shifted from water to the surfaces of leafy green vegetables [36], causing the contamination of the vegetables. A further possible contamination factor for leafy green production enterprises, especially organic farms, is the use of manure, which can contain a variety of pathogens. Therefore, it is essential to successfully implement a Hazard Analisys and Critical Control Point (HACCP) plan, an effective way to ensure food safety from harvest to consumption. The identification of critical control points (CCPs), i.e., steps during which control can be applied, is crucial to avoiding or eliminating a food-safety hazard or decreasing it to an acceptable level.

Further, the PMAxx real time RT-PCR results obtained in this study raise an important public health issue for the viral contamination of food in the vegetable-producing sector that should routinely adopt effective control tools for detecting viruses in foodstuffs. Specifically, in Commission Regulation (EC) $2073 / 05$, the only microbiological criteria for establishing the acceptability of vegetables are conventional fecal indicators, whereas Salmonella and E. coli are untrustworthy for demonstrating the presence or absence of viruses at the end of the production chain (at retail) [28,37]. This regulation does not take into consideration the risks derived from food contamination by enteric or emerging viral pathogens. Until recently, a major factor limiting the uptake of virus testing into regulatory food controls worldwide was the absence of any standardized and validated methods.

As high sensitivity is needed, virus detection in foods is in general based on molecular methods such as reverse transcription polymerase chain reaction (RT-PCR) $[28,38]$.

Reverse transcription (RT)-PCR and, more recently, real time RT-PCR methods, reveal only the presence of viral nucleic acid in the samples investigated and cannot be used to discriminate the presence of infectious viral particles in the food matrices analyzed [6,20].

From a sanitary point of view, the development of effective real time RT-PCR tools, useful not only for qualitative and quantitative detection but also for measuring virus infectivity, is an analytical priority. Therefore, the PMAxx real time RT-PCR assay described in this study, successfully applied to identify native and inactivated virus particles in RTE vegetables, assumes great analytical significance considering that, to the best our knowledge, this is the first study to detect the infectivity of NoV in naturally contaminated RTE salads.

The combination of PMAxx linked to real time PCR, in contrast with more labor-intensive and expensive techniques, such as animal or tissue-culture infectivity methods, is a promising alternative analytical strategy for assessing virus infectivity and can identify viruses for which there are no current standardized cell culture techniques, which opens up the possibility of effective risk assessment. 
In addition, we have demonstrated that PMAxx real time RT-PCR assay is suitable for the analysis of naturally contaminated RTE salad samples, giving a better evaluation of the infectious viral particles compared with NoV RNA detected by the molecular methods. In fact, based on our results, it easy to see that the amount of positive samples for NoV RNA at $74.8 \%$ was an overestimate, given that the quantity of salad samples containing native viral particles that are dangerous for public health was just $37.6 \%$.

\section{Conclusions}

Given that leafy green vegetables and related ready-to-eat (RTE) salads are main elements of current diets [5,39] and that NoV has been listed as a priority concern [2,40], future investigation is needed in this area focusing on the development of methods for assessing the presence/absence and infectivity of viruses in food products placed on the market, by performing an innovative virological fit-for-purpose risk assessment in a leaf vegetable production enterprise, although these findings could also be significant for effective risk assessments in composite and ethnic foods.

Furthermore, this study underlines the need to focus the legislator's attention on the presence of enteric viruses in vegetables in order to plan appropriate food-safety management systems, including good agricultural practices (GAP), good hygiene practices (GHP), and good manufacturing practices (GMP), assessing specific virus risks in vegetables.

\section{Future Perspective}

Despite being an innovative and rapid method, the PMAxx real time RT-PCR assay has limitations due to the possible inability of the intercalating dye to remove all RNA from the amplification not enclosed in the viral capsid. For this reason, further study is needed.

Cell cultures, although they represent an excellent and even more specific method, cannot give quick answers but need a few days and are not currently standardized. Therefore, since the safeguarding of public health requires immediate and preventive interventions, the PMAxx real time RT-PCR assay, could become the gold standard method to discriminate between native and inactivated viral particles, ensuring effective risk analysis and public health protection.

Author Contributions: V.T. designed the experiment; V.T., P.L., A.M., E.B. performed the experiments; P.L. analyzed the data; G.T. Supervision; V.T., A.D.P. Wrote the paper; C.B. Review \& editing. All authors have read and agreed to the published version of the manuscript.

Funding: This research received no external funding.

Conflicts of Interest: The authors declare no conflict of interest.

\section{References}

1. Bányai, K.; Estes, M.K.; Martella, V.; Parashar, U.D. Viral gastroenteritis. Lancet 2018, 392, 175-186. [CrossRef]

2. EFSA and ECDC. The European Union One Health 2018 Zoonoses Report. EFSA J. 2019, 17, 5926.

3. Berger, C.N.; Sodha, S.V.; Shaw, R.K.; Griffin, P.M.; Pink, D.; Hand, P.; Frankel, G. Fresh fruit and vegetables as vehicles for the transmission of human pathogens. Environ. Microbiol. 2010, 12, 2385-2397. [CrossRef]

4. Cheong, S.; Lee, C.; Song, S.W.; Choi, W.C.; Lee, C.H.; Kim, S.J. Enteric viruses in raw vegetables and groundwater used for irrigation in South Korea. Appl. Environ. Microbiol. 2009, 75, 7745-7751. [CrossRef]

5. Kokkinos, P.; Kozyra, I.; Lazic, S.; Bouwknegt, M.; Rutjes, S.; Willems, K.; Moloney, R.; de Roda Husman, A.M.; Kaupke, A.; Legaki, E.; et al. Harmonised investigation of the occurrence of human enteric viruses in the leafy green vegetable supply chain in three European countries. Food Environ. Virol. 2012, 4, 79-191. [CrossRef]

6. Terio, V.; Bottaro, M.; Pavoni, E.; Losio, M.N.; Serraino, A.; Giacometti, F.; Martella, V.; Mottola, A.; Di Pinto, A.; Tantillo, G. Occurrence of hepatitis A and E and norovirus GI and GII in ready-to-eat vegetables in Italy. Int. J. Food Microbiol. 2017, 249, 61-65. [CrossRef]

7. Bidawid, S.; Farber, J.M.; Sattar, A. Contamination of foods by food handlers: Experiments onHepatitis a virus transfer to food and its interruption. Appl. Environ. Microbiol. 2000, 66, 2759-2763. [CrossRef] 
8. Mottola, A.; Bonerba, E.; Bozzo, G.; Marchetti, P.; Celano, G.V.; Colao, V.; Terio, V.; Tantillo, G.; Figueras, M.J.; Di Pinto, A. Occurrence of emerging food-borne pathogenic Arcobacter spp. isolated from pre-cut (ready-to-eat) vegetables. Int. J. Food Microbiol. 2016, 236, 33-37. [CrossRef]

9. European Commission. Commission Regulation (EC) No 2073/2005 of 15 November 2005 on Microbiological Criteria for Foodstuffs; European Commission: Brussels, Belgium, 2005.

10. EFSA Panel on Biological Hazards. Scientific opinion on the risk posed by pathogens in food of non-animal origin. Part 2 (Salmonella and norovirus in leafy greens eaten raw as salads). EFSA J. 2014, 12, 118.

11. Haramoto, E.; Kitajima, M.; Hata, A.; Torrey, J.R.; Masago, Y.; Sano, D.; Katayama, H. A review on recent progress in the detection methods and prevalence of human enteric viruses in water. Water Res. 2018, 135, 168-186.

12. Malik, Y.S.; Verma, A.K.; Kumar, N.; Touil, N.; Karthik, K.; Tiwari, R.; Bora, D.P.; Dhama, K.; Ghosh, S.; Hemida, M.G.; et al. Advances in diagnostic approaches for viral etiologies of diarrhea: From the lab to the field. Front. Microbiol. 2019, 10, 1957. [CrossRef] [PubMed]

13. ISO/TS 15216-2. Microbiology of Food and Animal Feed-Horizontal Method for Determination of Hepatitis A Virus and Norovirus in Food Using Real-Time RT-PCR. Part 2: Method for Qualitative Detection; International Organization for Standardization: Geneva, Switzerland, 2017.

14. Parshionikar, S.; Laseke, I.; Fout, G.S. Use of Propidium Monoazide in reverse transcriptase PCR To distinguish between infectious and noninfectious enteric viruses in water samples. Appl. Environ. Microbiol. 2010, 76, 4318-4326. [CrossRef] [PubMed]

15. Hamza, I.A.; Jurzik, L.; Überla, K.; Wilhelm, M. Methods to detect infectious human enteric viruses in environmental water samples. Int. J. Hyg. Environ. Health 2011, 214, 424-436. [CrossRef]

16. Rodriguez, A.R.; Pepper, I.L.; Gerba, C.P. Application of PCR-Based methods to assess the infectivity of enteric viruses in environmental samples. Appl. Environ. Microbiol. 2009, 75, 297-307. [CrossRef] [PubMed]

17. Randazzo, W.; López-Gálvez, F.; Allende, A.; Aznar, R.; Sánchez, G. Evaluation of viability PCR performance for assessing norovirus infectivity in fresh-cut vegetables and irrigation water. Int. J. Food Microbiol. 2016, 229, 1-6. [CrossRef]

18. Fittipaldi, M.; Nocker, A.; Codony, F. Progress in understanding preferential detection of live cells using viability dyes in combination with DNA amplification. J. Microbiol. Methods 2012, 91, 276-289. [CrossRef]

19. Fuster, N.; Pintó, R.M.; Fuentes, C.; Beguiristain, N.; Bosch, A.; Guix, S. Propidium monoazide RTqPCR assays for the assessment of hepatitis A inactivation and for a better estimation of the health risk of contaminated waters. Water Res. 2016, 101, 226-232. [CrossRef]

20. Moreno, L.; Aznar, R.; Sánchez, G. Application of viability PCR to discriminate the infectivity of hepatitis A virus in food samples. Int. J. Food Microbiol. 2015, 201, 1-6. [CrossRef]

21. Yezli, S.; Otter, J.A. Minimum infective dose of the major human respiratory and enteric viruses transmitted through food and the environment. Food Environ. Virol. 2011, 3, 1-30. [CrossRef]

22. Randazzo, W.; Khezric, M.; Ollivier, J.; Le Guyaderd, F.S.; Díaz, J.R.; Aznara, R.; Sánchez, G. Optimization of PMAxx pretreatment to distinguish between human norovirus with intact and altered capsids in shellfish and sewage samples. Front. Microbiol. 2018, 9, 1973. [CrossRef]

23. Martínez-Martínez, M.; Diez-Valcarce, M.; Hernández, M.; Rodríguez-Lázaro, D. Design and application of nucleic acid standards for quantitative detection of enteric viruses by real-time PCR. Food Environ. Virol. 2011, 3, 92-98. [CrossRef] [PubMed]

24. da Silva, A.K.; Le Saux, J.C.; Parnaudeau, S.; Pommepuy, M.; Elimelech, M.; Le Guyader, F.S. Evaluation of removal of noroviruses during wastewater treatment, using real-time reverse transcription-PCR: Different behaviors of genogroups I and II. Appl. Environ. Microbiol. 2007, 73, 7891-7897. [CrossRef] [PubMed]

25. Scallan, E.; Hoekstra, R.M.; Angulo, F.J.; Tauxe, R.V.; Widdowson, M.A.; Roy, S.L.; Jones, J.L.; Griffin, P.M. Foodborne illness acquired in the United States major pathogens. Emerg. Infect. Dis. 2011, 17, 7-15. [CrossRef] [PubMed]

26. Rzezutka, A.; Cook, N. Survival of human enteric viruses in the environment and food. FEMS Microbiol. Rev. 2004, 28, 441-453. [CrossRef]

27. La Bella, G.; Martella, V.; Basanisi, M.G.; Nobili, G.; Terio, V.; La Salandra, G. Food-Borne viruses in shellfish: Investigation on norovirus and HAV presence in Apulia (SE Italy). Food Environ. Virol. 2017, 9, 179-186. [CrossRef] 
28. Terio, V.; Di Pinto, A.; Di Pinto, P.; Martella, V.; Tantillo, G. RNA extraction method for the PCR detection of hepatitis A virus in shellfish. Int. J. Food Microbiol. 2010, 142, 198-201. [CrossRef]

29. Loutreul, J.; Cazeaux, C.; Levert, D.; Nicolas, A.; Vautier, S.; Le Sauvage, A.L.; Perelle, S.; Morin, T. Prevalence of human noroviruses in frozen marketed shellfish, red fruits and fresh vegetables. Food Environ. Virol. 2014, 6, 157-168. [CrossRef]

30. Terio, V.; Bottaro, M.; Di Pinto, A.; Catella, C.; Chironna, M.; Bozzo, G.; Kingsley, D.H.; Bonerba, E.; Morea, A.; Martella, V. Outbreak of hepatitis A in Italy associated with frozen red currants imported from Poland: A case study. Food Environ. Virol. 2015, 7, 305-308. [CrossRef]

31. Chiapponi, C.; Pavoni, E.; Bertasi, B.; Baioni, L.; Scaltriti, E.; Chiesa, E.; Cianti, L.; Losio, M.N.; Pongolini, S. Isolation and genomic sequence of Hepatitis A virus from mixed frozen berries in Italy. Food Environ. Virol. 2014, 6, 202-206. [CrossRef]

32. Severi, E.; Verhoef, L.; Thornton, L.; Guzman-Herrador, B.R.; Faber, M.; Sundqvist, L.; Rimhanen-Finne, R.; Roque-Afonso, A.M.; Ngui, S.L.; Allerberger, F.; et al. Large and prolonged food-borne multistate hepatitis A outbreak in Europe associated with consumption of frozen berries, 2013 to 2014. Eurosurveillance 2015, 20, 21192. [CrossRef]

33. Serracca, L.; Rossini, I.; Battistini, R.; Goria, M.; Sant, S.; De Montis, G.; Ercolini, C. Potential risk of norovirus infection due to the consumption of "ready to eat" food. Food Environ. Virol. 2012, 4, 89-92. [PubMed]

34. Butot, S.; Putallaz, T.; Sánchez, G. Effects of sanitation, freezing and frozen storage on enteric viruses in berries and herbs. Int. J. Food Microbiol. 2008, 126, 30-35. [CrossRef] [PubMed]

35. Hewitt, J.; Leonard, M.; Greening, G.E.; Lewis, G.D. Influence of wastewater treatment process and the population size on human virus profiles in wastewater. Water Res. 2011, 45, 6267-6276. [CrossRef]

36. Baert, L.; Uyttendaele, M.; Vermeersch, M.; Van Coillie, E.; Debevere, J. Survival and transfer of murine norovirus 1, a surrogate for human noroviruses, during the production process of deep-frozen onions and spinach. J. Food Prot. 2008, 71, 1590-1597. [CrossRef] [PubMed]

37. Goyal, S.M.; Gerba, C.P.; Melnick, J.L. Human enteroviruses in oysters and their overlying waters. Appl. Environ. Microbiol. 1979, 37, 572-581. [CrossRef] [PubMed]

38. Di Pinto, A.; Forte, V.T.; Tantillo, G.M.; Terio, V.; Buonavoglia, C. Detection of hepatitis A virus in shellfish (Mytilus galloprovincialis) with RT-PCR. J. Food Prot. 2003, 66, 1681-1685. [CrossRef]

39. Taban, B.M.; Halkman, A.K. Do leafy green vegetables and their ready-to-eat [RTE] salads carry a risk of foodborne pathogens? Anaerobe 2011, 17, 286-287. [CrossRef]

40. Müller, L.; Rasmussen, L.D.; Jensen, T.; Schultz, A.C.; Kjelsø, C.; Barnadas, C.; Sigsgaard, K.; Larsen, A.R.; Widstrup Jensen, C.; Jeppesen, S.; et al. Series of norovirus outbreaks caused by consumption of green coral lettuce, Denmark, April 2016. PLoS Curr. 2016, 8. [CrossRef] 